\title{
BAGI HASIL DAN EVALUASI PERLAKUAN AKUNTANSI PEMBIAYAAN MUDHARABAH PADA BANK SYARIAH MANDIRI KANTOR CABANG PEMBANTU SUMENEP
}

\author{
Ita Dwi Agustin ${ }^{1}$, Isnani Yuli Andini ${ }^{2}$, Imam Darul Firmansyah ${ }^{3}$ \\ ${ }^{1,2,3)}$ Fakultas Ekonomi dan Bisnis Universitas Wiraraja \\ Email: itaaagustin09@gmail.com ${ }^{1}$
}

\begin{abstract}
ABSTRAK
Pembiayaan mudharabah merupakan pembiayaan berdasarkan akad kerja sama antara pemilik dana (shahibul maal) dengan pengelola dana (mudharib) untuk memperoleh keuntungan dengan porsi pembagian hasil usaha yang telah disepakati bersama pada awal akad. Pembagian nisbah dapat dilakukan dengan prinsip Profit Sharing (bagi laba) atau Revenue Sharing (bagi hasil). Pembiayaan mudharabah diatur dalam PSAK Syariah No.105 mengenai akuntansi mudharabah, yang mengatur bagaimana perlakuan terhadap pengakuan, pengukuran, penyajian, dan pengungkapan. Objek penelitian ini pada Bank Syariah Mandiri Kantor Cabang Pembantu Sumenep. Jenis penelitian yang digunakan adalah jenis penelitian deskriptif komparatif.

Hasil penelitian menunjukkan bahwa perhitungan bagi hasil pada Bank Syariah Mandiri Kantor Cabang Pembantu Sumenep belum sesuai dengan PSAK No.105, karena Bank Syariah Mandiri Kantor Cabang Pembantu Sumenep menggunakan proyeksi keuntungan, yang mana memudahkan bank dalam memperkirakan seberapa mampunya pihak LKS dalam mengembalikan sejumlah dana yang bank berikan. Sedangkan untuk perlakuan akuntansi pembiayaan mudharabah pada Bank Syariah Mandiri Kantor Cabang Pembantu Sumenep sudah sesuai dengan PSAK No.105.
\end{abstract}

Kata Kunci : Pembiayaan Mudharabah; Bagi Hasil; Perlakuan Akuntansi; PSAK No.105

\section{INTRODUCTION}

Pembiayaan mudharabah merupakan pembiayaan berdasarkan akad kerja sama antara pemilik dana (shahibul maal) dengan pengelola dana (mudharib) untuk memperoleh keuntungan sesuai dengan porsi pembagian hasil usaha yang telah disepakati bersama pada awal akad. Mudharabah memberikan manfaat kepada pemilik modal berupa pengelolaan usaha dan kepada orang yang diberi modal berupa harta. Dalam pembagian nisbah (keuntungan) mudharabah dapat dilakukan berdasarkan prinsip Profit Sharing (bagi laba) atau Revenue Sharing (bagi hasil). Besarnya penentuan nisbah antara kedua belah pihak ditentukan sesuai kesepakatan bersama dan harus terjadi dengan adanya kerelaan dari masing-masing pihak tanpa adanya unsur paksaan. Salah satu pihak tidak diperkenankan mengambil seluruh keuntungan tanpa membagi kepada pihak yang lain.

Dalam pembiayaan mudharabah membutuhkan suatu kerangka akuntansi yang menyeluruh yang mampu menghasilkan pengukuran yang tepat dan sesuai. Semua aspek yang berkaitan dengan akuntansi tersebut diatur dalam PSAK (Pernyataan Standar Akuntansi Keuangan), yang merupakan kerangka acuan dalam prosedur yang berkaitan dengan penyajian laporan keuangan. Dengan adanya standar akuntansi maka akan memberikan banyak manfaat bagi pihak internal maupun eksternal, salah 
satunya yaitu sebagai perbandingkan laporan keuangan perusahaan dengan periode sebelumnya maupun dengan laporan keuangan perusahaan lain.

Pembiayaan mudharabah diatur dalam PSAK Syariah No.105 mengenai akuntansi mudharabah, yang mengatur bagaimana seharusnya perlakuan terhadap penerapan bagi hasil, pengakuan, pengukuran, penyajian, dan pengungkapan transaksi mudharabah. PSAK Syariah tersebut juga merupakan suatu proses evaluasi apakah sistem perbankan yang ada saat ini telah dijalankan sesuai dengan peraturan syariah dan prinsip-prinsip syariah.

Objek penelitian yang dipilih oleh peneliti adalah Bank Syariah Mandiri Kantor Cabang Pembantu Sumenep, hal tersebut dilakukan untuk mengetahui bagaimana perhitungan bagi hasil dan perlakuan akuntansi atas pembiayaan mudharabah. Pemilihan Bank Syariah Mandiri dikarenakan Bank Syariah Mandiri merupakan sebuah Bank Syariah yang pertumbuhan pembiayaan atas mudharabah menjadi salah satu produk yang paling diminati oleh calon nasabah dibandingkan dengan produk pembiayaan lainnya. Jika kita berbicara mengenai perlakuan akuntansi yang umum tentu hal ini merujuk pada PSAK yang dalam hal ini dapat diketahui dari PSAK 105. Selain dari PSAK 105 tentu juga dikaitkan dengan peraturan yang ada di perbankan syariah. Beberapa penelitian terdahulu yang menjadi acuan maupun pedoman bagi peneliti dalam melaksanakan penelitian ini menyebutkan bahwa beberapa Bank Syariah Mandiri belum sepenuhnya mengikuti peraturan perbankan syariah, sehingga hal ini menjadi alasan untuk dilakukan penelitian ini.

\section{LITERATURE REVIEW}

a. Definisi Pembiayaan

Dalam Undang-Undang Perbankan Syariah No.21 Tahun 2008 pasal 1 ayat (25) yang dimaksud pembiayaan adalah penyediaan atau tagihan yang dipersamakan dengan itu berupa transaksi bagi hasil, sewa-menyewa, jual beli, pinjam meminjam, dan transaksi sewa menyewa jasa berdasarkan persetujuan atau kesepakatan antara Bank Syariah/UUS dan pihak lain yang mewajibkan pihak yang dibiayai/diberi fasilitas dana untuk mengembalikan dana tersebut setelah jangka waktu tertentu dengan imbalan ujrah, tanpa imbalan, atau bagi hasil.

Sedang menurut fatwa Dewan Syariah MUI No. 07/DSN-MUI/IV/2000, pembiayaan mudharabah adalah pembiayaan yang disalurkan oleh LKS kepada pihak lain untuk suatu usaha yang produktif, dimana LKS sebagai shahibul maal (pemilik dana) membiayai 100\% kebutuhan suatu proyek (usaha), sedangkan pengusaha (nasabah) bertindak sebagai mudharib atau pengelola usaha.

\section{b. Definisi Mudharabah}

PSAK 105 mendefinisikan mudharabah sebagai akad kerjasama usaha yang dilakukan oleh dua pihak di mana pihak pertama sebagai pemilik modal (shahibul maal) menyediakan seluruh dana, sedangkan pihak lainnya sebagai pengelola dana (mudharib). Keuntungan usaha secara mudharabah dibagi atas kesepakatan yang ada dalam kontrak, sedangkan apabila terjadi kerugian maka ditanggung oleh pemilik modal selama kerugian tersebut bukan akibat dari kelalaian pengelola.

\section{c. Definisi Bagi Hasil}

Dalam sistem perbankan Islam, bagi hasil merupakan suatu mekanisme yang dilakukan oleh bank Islam (mudharib) dalam 
upaya memperoleh hasil dan membagikannya kembali kepada para pemilik dana (shahibul mal) sesuai kontrak yang disepakati di awal bersama. Adapun pendapatan yang dibagikan adalah pendapatan yang sebenarnya telah diterima (cash basis) sedangkan pendapatan yang masih dalam pengakuan (accrual basis) tidak dibenarkan untuk dibagi antara mudharib dan shahibul maal.

\section{d. Metode Bagi Hasil}

Terdapat 2 sistem dalam metode bagi hasil, yaitu:

1. Bagi Laba (Profit Sharing), bagi hasil yang dihitung dari pendapatan setelah dikurangi biaya pengelolaan dana.

2. Bagi Hasil (Revenue Sharing), bagi hasil yang dihitung dari total pendapatan pengelola dana.

\section{METHODS}

Penelitian ini merupakan penelitian kualitatif komparatif yang akan membandingkan kondisi yang terjadi di Bank Syariah Mandiri Kantor Cabang Pembantu Sumenep dengan PSAK 105. Sumber data penelitian ini menggunakan sumber data primer yang diperoleh dengan cara wawancara langsung dengan sumber informan. Adapun informan dalam penelitian ini adalah Bapak Dwi Krisdiyanto selaku staff consumer banking dan Bapak Fajar Sugiarto selaku staff operating officer.

Teknik pengumpulan data dalam penelitian ini, yaitu observasi langsung pada objek yakni di Bank Syariah Mandiri Kantor Cabang Pembantu Sumenep. Wawancara, dengan mewawancarai informan guna memperoleh data yang lebih mendalam terkait penelitian ini. Dokumentasi, yaitu berupa brosur, laporan keuangan, dokumen-dokumen seperti tabel perhitungan nisbah, jadwal dan perhitungan angsuran.
Teknik analisis data pada penelitian ini yaitu pengumpulan data, diperoleh dengan cara observasi ke objek penelitian, wawancara dengan informan dan dokumentasi. Reduksi data, peneliti mengumpulkan data dengan cara memilih dan menggolongkan hal-hal pokok. Penyajian data, dalam penyajian data, peneliti menyajikan data yang tersusun dan menguraikan jawaban yang telah diberikan informan. Penarikan kesimpulan akan menarik kesimpulan terkait data yang telah diperoleh dan diolah sebelumnya agar dapat ditemukan suatu kesimpulan yang benar terkait dengan penelitian ini berdasarkan data yang valid dan akurat dari lapangan. Uji keabsahan data yang digunakan adalah triangulasi teknik yang mana peneliti akan mengecek data kepada sumber yang sama dengan teknik yang berbeda. Data tersebut diperoleh dari hasil wawancara, observasi dan dokumentasi.

\section{RESULTS AND DISCUSSIONS}

a. Perlakuan Akuntansi Pembiayaan Mudharabah Pada Bank Syariah Mandiri Kantor Cabang Pembantu Sumenep

Dalam pembiayaan ini, Bank Syariah Mandiri bertindak sebagai pemilik dana (shahibul maal) yang mana memberikan bantuan pembiayaan kepada nasabah yang bertindak sebagai pengelola dana (mudharib). Selain itu dalam melakukan transaksi, Bank Syariah Mandiri juga bertindak sebagai pengelola dana (mudharib) yang dituangkan dalam produk tabungan.

\section{Pengakuan Pembiayaan Mudharabah Pada Bank Syariah Mandiri Kantor Cabang Pembantu Sumenep}

Berikut ini contoh kasus pembiayaan mudharabah pada Bank 
Syariah Mandiri Kantor Cabang Sumenep :

Koperasi memiliki kebutuhan untuk membiayai anggotanya dengan total kebutuhan Rp. 35.000.000.000. Koperasi menentukan besarnya margin (ERR Koperasi) kepada para anggotanya sebesar $18 \%$ flat pa. Kemudian Koperasi mengajukan pembiayaan kepada Bank Syariah Mandiri untuk berakad mudharabah selama 3 tahun (36 bulan). Bank Syariah Mandiri menentukan besarnya margin (ERR Bank) sebesar $14 \%$.

Pada saaat Bank Syariah Mandiri Kantor Cabang Pembantu Sumenep melakukan pencairan pembiayaan mudharabah maka bersamaan itu pula timbul biaya yang terjadi karena proses pencairan tersebut. Biaya-biaya yang terjadi karena adanya proses pencairan pembiayaan itu dibebankan kepada nasabah dengan cara mengurangi akun rekening nasabah dan tidak mengurangi pokok pembiayaan mudaharabah.

2. Pengukuran

Pembiayaan

Mudharabah Pada Bank Syariah Mandiri Kantor Cabang Pembantu Sumenep

Bank Syariah Mandiri Kantor

Cabang Pembantu Sumenep, mengukur pembiayaan mudharabah sejumlah uang yang dibayarkan Bank Syariah Mandiri kepada Nasabah pada saat pencairan dana yaitu setelah akad pembiayaan disetujui

\section{Penyajian}

Pembiayaan

\section{Mudharabah Pada Bank Syariah} Mandiri Kantor Cabang Pembantu Sumenep
Bank Syariah Mandiri yang ada di Sumenep merupakan kantor cabang pembantu, sehingga segala sesuatu yang berkaitan dengan laporan keuangan terpusat di kantor pusat. Bank cabang hanya melaporkan aktivitas usahanya sesuai dengan kegiatan operasional yang dijalankan, kemudian bank pusat akan merekap seluruh laporan yang diterima dari cabang dan merealisasikannya dalam laporan keuangan.

Penyajian dalam kaitannya dengan pembiayaan mudharabah oleh Bank Syariah Mandiri disajikan dalam laporan keuangan (neraca) pada sisi aktiva sebesar tagihan Bank Syariah Mandiri kepada nasabah, sedangkan untuk komponen laba/rugi disajikan dalam bentuk pengelompokan pendapatan dan beban menurut sistem yang digunakan.

4. Pengungkapan Pembiayaan Mudharabah Pada Bank Syariah Mandiri Kantor Cabang Pembantu Sumenep

Pada Bank Syariah Mandiri Kantor Pembantu Sumenep, dalam hal mengungkapkan isi kesepakatan berdasarkan jenisnya tercantum dalam dokumen perjanjian. Dokumen perjanjian tersebut antara lain berisi, jumlah plafond, jangka waktu, nama-nama anggota yang meminjam, jenis usaha, porsi nisbah dan masih banyak lagi lainnya

\section{CONCLUSION}

Berdasarkan hasil penelitian dan analisis yang dilakukan oleh peneliti maka peneliti menyimpulkan sebagai berikut: 
Pada prakteknya di Bank Syariah Mandiri Kantor Cabang Pembantu Sumenep belum benar-benar menerapkan akad mudharabah, melainkan memberikan pinjaman yang mana jangka waktu usaha, tata cara pengambilan dana dan pembagian keuntungan berdasarkan ketentuan dari Bank. Perjanjiannya menggunaan penggabungan dua akad, yakni akad mudharabah wal murabahah). Selain itu, pada Bank Syariah Mandiri Kantor Cabang Pembantu Sumenep dalam parakteknya tidak terjadi perhitungan pembagian hasil usaha. Namun yang ada hanya jadwal dan perhitungan angsuran selama masa kerjsa sama.

Perlakuan akuntansi pembiayaan mudharabah pada Bank Syariah Mandiri Kantor Cabang Pembantu Sumenep yang terdiri dari pengakuan, pengukuran, penyajian, dan pengungkapan sudah cukup sesuai dengan PSAK 105. Hanya saja pada perhitungan pembagian hasil usaha belum sesuai dengan PSAK 105.

Selain itu dari hasil penelitian dan pembahasan yang telah disimpulkan di atas, maka peneliti memiliki saran sebagai berikut:

1. Hendaknya Bank Syariah Mandiri Kantor Cabang Pembantu Sumenep menyempurnakan akad pembiayaan mudharabah agar sesuai dengan PSAK 105, karena penggabungan dua akad antara akad mudharabah dengan akad murabahah pada pembiayaan mudharabah tersebut tidak memiliki dasar hukum yang kuat dan memang tidak ada dalam PSAK 105.

2. Hendaknya Bank Syariah Mandiri Kantor Cabang Pembantu Sumenep dalam melakukan setiap transaksi yang ada baik pada perjanjian mudharabah ataupun produk perbankan lainnya agar tetap mengacu pada PSAK 105 dan sesuai dengan tujuan dari prinsip perbankan syariah.
3. Perlu diadakan pengkajian dan evaluasi intern pada Bank Syariah Mandiri Kantor Cabang Pembantu Sumenep dalam penerapan PSAK 105 pada produk pembiayaan khususnya produk mudharabah. Bank Syariah Mandiri Kantor Cabang Pembantu Sumenep diharapkan untuk terus mengikuti perkembangan peraturan perbankan syariah terutama mengenai pembiayaan mudharabah terkait perhitungan nisbah bagi hasil sehingga dapat sesuai dengan prinsp syariah.

\section{REFERENCES}

Aliyah. 2015. Analisis Penerapan Pernyataan Standar Akuntansi Keuangan (PSAK) 105 Pada Pembiayaan Mudharabah di Bank Muamalat Indonesia. Skripsi S1 Program Sarjana Komunikasi Islam Universitas Islam Negeri Syarif Hidayatullah, Jakarta.

Antonio, Muhammad Syfi'i. 2001. Bank

Syariah: Dari Teori Ke Praktik. Jakarta. Gema Insani Press

Ikatan Akuntan Indonesia (IAI). Pernyataan Standar Akuntansi Keuangan No.105, Akuntansi Mudharabah. Jakarta: 2007

Khumaidi, Makhbub. 2014. Kesesuaian Praktik Pembiayaan Murabahah dan Mudharabah Dengan Psak NO. 201 Dan 105 Pada BMT GKBI Syari'ah Cabang Yogyakarta. Skripsi S1 Program Sarjana Ekonomi Islam Univesitas Islam Negeri Sunan Kalijaga, Yogyakarta.

Nurhayati, Sri, Wasilah. 2014.Akuntansi Syariah di Indonesia Edisi 3. Jakarta: Salemba Empat.

Rokhlinasari, Sri, dan Dewi Astuti. 2016. Penerapan Standar Akuntansi Keuangan (PSAK) No. 105 Pada Pembiayaan Mudharabah di Bank BNI 
Syariah Cabang Cirebon dalam Jurnal Program Studi Perbankan Syari'ah Fakultas Syari'ah dan Ekonomi Islam

Rosita, Siti Ita, dan Abdul Rahman. 2011. Evaluasi Penerapan Pembiayaan Mudharabah dan Pengaruhnya Terhadap laba Perusahaan (Studi Kasus Pada PT. Bank Muamalat Indonesia Tbk, Cabang Bogor) dalam Jurnal Ilmiah Ranggagading, Vol.11 No.1, April 2011

Sandy, Kunthi Fahmar. 2016. Bank Syariah Mandiri Cetak Pertumbuhan Laba $26,67 \%$.

http://ekbis.sindonews.com/read/113133

2/bank-syariah-mandiri-cetak-

pertumbuhan -laba-2667-1471243362. Diakses 19 April 2018.

Sugiyono. 2017. Metodologi Penelitian Kuantitatif, Kualitatif, R\&D. Bandung: Alfabeta.

Tsabita, Rachmania, Iwan Triyuwono, M. Achsin. 2015. "Mengungkap

Ketidakadilan Dalam Praktik

Pembiayaan Mudharabah: Studi

Fenomenologi" dalam Jurnal Fakultas Ekonomi dan Bisnis, Vol. 6 No.1, Januari 2015.

Turrosifa, Kamila, Akhmad Riduwan. 2013. "Penerapan PSAK No. 105 Dalam Transaksi Pembiayaan Mudharabah Pada Bank Syariah Bukopin Cabang Sidoarjo" dalam Jurnal Ilmu dan Riset Akuntansi, Vol. 2 No. 8, 2013.

Vidada, Irwin Ananta. 2015. "Tinjauan Praktek Akad Mudharabah Perbankan Syariah Di Indonesia” dalam Jurnal
Sistem Informasi Akuntansi, Vol. II No. 1, April 2015.

Wahyuni, Nining Sri. 2016. “Analisis Fikih Sistem Pembiayaan Mudharabah Dalam Praktik dan Peraturan Perundang-Undangan Perbankan Syariah" dalam Jurnal Lecturer of Teacher Training and Educations Sciences Faculty, Vol. 2 No. 1, JanuariJuni 2016.

Wasman dan Asep Hilman Nuryaman. 2017. "Status Ganda Lembaga Intermediasi Keuangan Perbankan Syariah Dalam Menjalankan Akad Mudharabah" dalam Jurnal Fakultas Syariah dan Ekonomi Islam, Vol. 2 No.1, Juni 2017.

Wulandari, Tri. 2016. Analisis Implementasi Psak No.105 Akuntansi Mudharabah Pada Baitul Mal Wat Tamwil (Bmt) Sidogiri di Kecamatan Pagak Kabupaten Malang. Program Studi Akuntansi, Fakultas Ekonomika dan Bisnis Universitas Kanjuruhan, Malang.

Yaya, Rizal, Aji Erlangga Martawireja, Ahim Abdurahim. 2014. Akuntansi Perbankan Syariah: Teori dan Praktik Kontemporer Edisi 2. Jakarta: Salemba Empat.

Zulva, Nur Aini. 2015. Praktek Pembiayaan Mudharabah Pada BMT An-Nawawi Purworejo. Tugas Akhir D3 Program Studi Perbankan Syariah Fakultas Ekonomi dan Bisnis Uin Walisongo, Semarang.

www.ojk.go.id 